\section{Soviet space}

\section{Gagarin year tells more}

SOVIET media comments on the twentyfifth anniversary two weeks ago of Yuri Gagarin's first space flight by a human being have been memorable not only for the ritual honorifics of the occasion but for the interesting details they have provided of the early days of the Soviet space programme. No doubt this reflects the current policy of openness shown on these affairs.

Gagarin himself died in a jet crash in 1968, apparently during a refresher course on returning to the cosmonaut programme after several years of ceremonial duties. His place in the jubilee celebrations was taken by the German Titov, his back-up, and subsequently the second Soviet citizen in space. Addressing a cere-

\section{Tamarins to go home}

\section{Tokyo}

TEN golden-headed lion tamarins imported illegally into Japan three years ago are to be returned to Brazil. The announcement, made at an environmental committee meeting in the Diet, represents a considerable victory for the World Wildlife Fund branch in Japan, which has been quietly lobbying the government for the monkeys' return since last year.

The plight of the tamarins caught the media's attention when the director of the Rio de Janeiro Primate Center appeared on television during a private visit to Japan protesting that not only had tamarins been illegally imported into Japan but that they were not being properly looked after in the zoos that had subsequently bought them (see Nature 318, 200; 1985).

The golden-headed lion tamarin is one of the world's rarest primates, with perhaps as few as $\mathbf{2 0 0}$ remaining in their native habitat in southeastern Brazil. Those that came into Japan were sneaked in with false papers showing them to have been bred in captivity in Guyana, a falsehood that Japanese customs officials should easily have been able to spot. Captive breeding programmes are under way only at Rio de Janeiro and the zoo at Jersey in the United Kingdom.

Although the Japanese government has agreed to ensure that the tamarins will go back to Brazil, the World Wildlife Fund is likely to find itself with the bill and the responsibility for looking after the animals on their journey home. Negotiations are under way over compensation for the owners of the tamarins and over where they will go back to in Brazil. No problems are anticipated in shipping them: the Belgian government recently successfully returned without loss 16 animals illegally acquired by an animal dealer.

US space monial meeting in Moscow's Hall of Columns Titov revealed that medical and biological research on the effect of rocket flight on living organisms was begun as early as 1951 - in other words, during the last months of the Stalin era. This is a remarkable statement, as, so far as is known, Stalin's only interest in rockets at that time was as missiles; moreover, Sergei Korolev, who under Khruschev was to become chief designer of the space programme, was still, at that time, technically an unrehabilitated "traitor".

The cosmonaut training programme, Titov claims, began early in 1960, and after considering the work patterns of a number of groups, including divers, polar workers and mountaineers, it was decided to recruit air fighter-pilots, who, as Korolev put it, are "universal specialists". Two hundred pilots, Titov said, were initially selected, of whom just 20 got through the physical and medical examinations and six were short-listed for "intensive training" for the Vostok flight.

The same atmosphere of openness, at least on non-technical issues, pervaded the entire celebrations. In a press conference from on board the Mir space station, cosmonaut Vladimir Solov'ev admitted that some of the on-board Mir equipment was giving trouble, while another tele- vision programme, starring cosmonauts Valerii Ryumin and Aleksei Lenonov, dealt with emergency situations in space during the past 25 years.

As far as future developments are concerned, however, the celebrations revealed little that had not already been announced by the Soviet planners or deduced by foreign Baikonur watchers. Mir station was praised as the "base port" for a future manned permanently operating scientific research complex, and there were numerous calls for increased international cooperation. The Apollo-Soyuz link-up of 1975 and the recent Vega-Giotto project were hailed not only as notable achievements in themselves but as possible precursors of the World Organization for Space Study and Research for Peaceful Purposes which the Soviet Union would like to see established. Addressing the ceremonial meeting, Academician Vladimir Kotel'nikov noted that the Soviet Union is now planning several "major international projects" including the training of Syrian and French teams to work aboard Mir.

Although, naturally, nobody would voice an objection on such an auspicious occasion, the fact that the French are to have a second turn must come as a disappointment to some of the Soviet Union's junior partners in Interkosmos, for whom there has so far been no suggestion of a second manned mission.

Vera Rich

\title{
Titan blows up on pad
}

Washington

A TrTAn 34D rocket carrying a military satellite exploded seconds after lifting off from Vandenberg Air Force Base in California last week, further crippling US space efforts already in disarray folowing the shuttle accident earlier this year. The explosion marked the second failure in a row for the normally reliable Titan rocket. A Titan 34D exploded several minutes into its flight last August, when a turbopump failed at the same time as a fuel leak developed.

The Department of Defense uses Titan rockets to launch military satellites too heavy for the smaller Delta and Atlas Centaur rockets. Titan flights have been put on hold until an Air Force accident investigation team headed by Colonel Nathaniel Lindsey completes his report on last week's incident. At this stage, the Air Force will not speculate on possible causes of the accident.

Although the Department of Defense mission was classified, there is much speculation that it was a $\mathrm{KH}-11$ photoreconnaissance satellite, the device believed to have been lost in the Titan accident last year. This leaves just one functioning $\mathrm{KH}-11$ in orbit, according to John Pike of the Federation of American Scientists, with no replacements available. Launched in December 1984, the remaining $\mathrm{KH}-11$ is expected to last only until late 1987. The next generation of photo-reconnaissance satellites, dubbed KH-12, must be launched aboard the shuttle, raising fears that for a period of time the United States may be without spacebased photo-reconnaissance ability. Although Pike believes the operational KH11 will last until a new satellite can be launched, a gap in reconnaissance observations could have a negative affect on arms negotiations since US verification would be hampered.

The loss of the Titan rocket will place additional burdens on the already crowded shuttle schedule once flights resume. The National Aeronautics and Space Administration has already indicated that missions with national security objectives will have first claim to space aboard the shuttle. A new expandable launch vehicle being built for military payloads is not expected to be ready until 1988. Shuttle flights are expected to resume some time next year. 